\title{
PENGEMBANGAN DESAIN FREE ENERGY GENERATOR BERBAHAN MAGNET NEODYMIUM BERBASIS SOLIDWORKS UNTUK SISTEM RECHARGING PROTOTYPE GANESHA ELECTRIC GENERASI II UNDIKSHA
}

\author{
K. Bayu Triana1), K. Rihendra Dantes ${ }^{1)}$, I. N. Pasek Nugraha2) \\ Program Studi Pendidikan Teknik Mesin, Fakultas Teknik dan Kejuruan \\ Universitas Pendidikan Ganesha \\ Singaraja, Indonesia \\ e-mail: komank.bayu.triana@undiksha.ac.id, rihendra-dantes@undiksha.ac.id, \\ paseknugraha@undiksha.ac.id
}

\begin{abstract}
ABSTRAK
Sejalan dengan perkembangan ilmu pengetahuan ditemukan bahwa listrik dan magnet memiliki keterkaitan satu dengan yang lainnya, magnet dalam sebuah sistem pembangkitan terdapat pada bagian generator, dimana generator ini dapat menghasilkan listrik oleh putaran yang bersamaan dengan putaran turbin dengan adanya bantuan sumber-sumber energi. Namun ternyata magnet juga dapat menjadi sumber energi penggerak bagi generator itu sendiri. Penelitian ini dilakukan berdasarkan konteks permasalahan dalam hal ini menyangkut tentang perangcangan desain free energy generator berbasis magnet neodymium sebagai sumber energi kelistrikan sekaligus pengisian (recharging) yang akan diterapkan pada prototype ganesha electric generasi II UNDIKSHA. Penelitian pengembangan desain ini menggunakan perangkat lunak Solidworks 2018, tujuan penelitian ini antara lain (1) untuk mengetahui bagaimana cara perancangan free energy generator, (2) untuk mengetahui tingkat kelayakan desain berdasarkan penilaian dari ahli materi, (3) untuk mengetahui tingkat kelayakan desain berdasarkan uji kelompok kecil dan besar. Penelitian ini menggunakan rancangan Research and Development. Sedangkan untuk model yang digunakan yaitu Quality Function Deployment (QFD). Berdasarkan hasil analisis data yang dilakukan, diperoleh kesimpulan bahwa penelitian pengembangan desain free energy generator berbasis magnet neodymium mendapatkan hasil validasi yaitu (1) hasil tanggapan ahli materi $91 \%$ dengan kualifikasi sangat layak, (2) hasil tanggapan kelompok kecil 93,33\% dengan kualifikasi sangat layak, dan (3) hasil tanggapan kelompok besar $91,64 \%$ dengan kualifikasi sangat layak.
\end{abstract}

Kata Kunci: Listrik, Desain, Free Energy Generator, Recharging.

\section{ABSTRACT}

In line with the development of science knowledge, it had been found that the electricity and magnetism have relevance to one another. Magnets in a generation system are located on the generator, where this generator can produce electricity by spinning along with the turbine rotation with the help of energy sources. But apparently, the magnet can also be a source of driving energy for the generator itself. This research was conducted based on the context of the problem. In this case, concerned on the design of free energy generator neodymium magnetic based on the source of electricity as well as the recharging that would be applied to the Ganesha Electric Prototype, Generation II, UNDIKSHA. This design development research used software Solidworks 2018. The purpose of this study were; (1) to find out how to design free energy generators, (2) to determine the level of design feasibility based on the assessment of material experts, (3) to determine the level of design feasibility based on small and large test groups. This study used a design Research and Development. Whereas the model used is Quality Function Deployment (QFD). Based on the results of data analysis conducted, it was concluded that the research development of design free generator neodymium magnetic based on validation results obtained; (1) the results of material expert responses $91 \%$ 
with very decent qualifications, (2) the results of small group responses $93.33 \%$ with very decent qualifications, and (3) the results of a large group response of $91.64 \%$ with very decent qualifications.

Keywords: Electricity, Design, Free Energy Generator, Recharging

\section{PENDAHULUAN}

Listrik sangat dibutuhkan pada zaman modern saat ini. Karena sesuai dengan perkembangan zaman, manusia ingin sesuatu yang lebih praktis dan cepat. Oleh karena itu para ilmuan berusaha menenukan alat-alat yang dapat mempermudah pekerjaan manusia. Alat tersebut sebahagian besar menggunakan energi listrik. Energi listrik sangat fleksibel dan dapat dirubah ke bentuk energi lainnya seperti energi mekanik, energi panas, energi bunyi, energi kimia dan energi gerak. Sulit dibayangkan bagaimana dunia ini jika hingga saat ini manusia tidak dapat memanfaatkan listrik, berabad-abad telah dijalani dalam sejarah perkembangan kelistrikan untuk mengubah pengetahuan menjadi teknologi seperti sekarang ini. Energi listrik adalah energi yang berasal dari muatan listrik yang menimbulkan medan listrik statis atau bergeraknya elektron pada konduktor (pengantar listrik) atau ion (positif atau negatif) pada zat cair atau gas. Listrik memiliki satuan Ampere yang disimbolkan dengan (A) dan tegangan listrik dengan satuan Volt yang disimbolkan dengan (V) dengan ketentuan kebutuhan pemakaian daya listrik Watt yang disimbolkan dengan (W). Energi listrik dapat diciptakan oleh sebuah energi lain dan bahkan sanggup memberikan energi yang nantinya dapat dikonversikan pada energi yang lain lagi. Hingga saat ini PLN merupakan Perusahaan Listrik Negara yang bertugas untuk melayani dan memenuhi kebutuhan listrik masyarakat Indonesia.

Pengembangan energi alternatif baru dan terbarukan sedang digalakkan melalui kebijakan-kebijakan pemerintah untuk mendorong dan memfasilitasi pemanfaatan sumber energi terbarukan, serta untuk mengatasi krisis sumber energi dan pemanasan global yang di akibatkan dari penggunaan sumber energi fosil. Energi terbarukan berasal dari proses alami dan kemungkinan tidak akan pernah habis. Energi terbarukan adalah istilah yang digunakan untuk menggambarkan energi dari sumber yang alami regenerasi dan hampir tak terbatas. Ini termasuk energi surya, energi angin, tenaga air, biomassa (berasal dari tumbuhan), energi panas bumi, energi laut dan khususnya energi magnet. Peningkatan penggunaan energi terbarukan bisa mengurangi pembakaran bahan bakar fosil (batubara, minyak bumi, dan gas alam), menghilangkan polusi udara yang terkait dan emisi karbon dioksida, dan berkontribusi untuk kemandirian energi nasional. Banyak pengamat berharap bahwa energi alternatif ini suatu hari dapat memberikan sumber energi jauh lebih baik dibandingkan konvensional.

Sejalan dengan perkembangan ilmu pegetahuan ditemukan bahwa listrik dan magnet memiliki keterkaitan satu dengan yang lainnya. Sehingga sekarang ini, dengan menggunakan arus listrik kita dapat menimbulkan medan magnet di sekitar logam. Magnet memang menjadi bagian penting dalam sebuah sistem pembangkitan listrik, apapun itu sumber energi pembangkitnya baik Pembangkit Listrik Tenaga Air (PLTA), Pembangkit Listrik Tenaga Uap (PLTU), Pembangkit Listrik Tenaga Gas Uap (PLTGU), Pembangkit Listrik Tenaga Bayu (PLTB), dan beberapa jenis pembangkit listrik lainnya. Mungkin hanya pembangkit listrik tenaga surya (solar cell) serta pembangkit listrik dari fuel cell yang sama sekali tidak menggunakan komponen magnet dalam sistem pembangkitan listriknya.

Magnet dalam sebuah sistem pembangkitan terdapat pada bagian generator, dimana generator ini dapat menghasilkan listrik oleh putaran yang bersamaan dengan putaran turbin dengan adanya bantuan sumber-sumber energi seperti energi potensial air, angin, uap, dan lain sebagainya. Namun ternyata magnet juga dapat menjadi sumber energi penggerak bagi generator itu sendiri. 
Pembangkit listrik tenaga magnet atau sering disebut sebagai free energy generator karena tidak memerlukan energi/biaya yang cukup banyak untuk menghasilkan listrik serta dapat berlangsung secara terus-menerus.

Prinsip kerjanya cukup sederhana, yaitu memanfaatkan gaya dari arah flux magnetik yang berlawanan dapat membuat magnet lainnya bergerak. Jika flux magnet yang berlawanan tersebut disusun dari beberapa buah magnet sedemikian rupa sehingga magnet-magnet yang berfungsi sebagai stator memicu pergerakan dari magnet-magnet lainnya yang berfungsi sebagai rotor. Kemudian dari bagian rotor ini dapat disambungkan dengan bagian dari magnet lainnya yang berfungsi sebagai generator. Dari generator yang mulai bekerja (berputar) maka akan menghasilkan energi listrik yang akan menyebabkan lampu LED akan menyala.

Dalam kehidupan sehar-hari, kita biasa menggunakan alat-alat transportasi seperti mobil, motor, bus, dan lain sebagainya. Alat-alat transportasi tersebut sangat membantu kita dalam mengefisiensikan waktu dan tenaga, namun tentu ada harga yang harus dibayar untuk semua kenyamanan tersebut. Motor maupun mobil yang kita kenal dalam kehidupan sehari-hari banyak jenisnya, dilihat dari bahan bakarya, ada yang menggunakan bensin, solar, gas, listrik, dan bahkan tenaga surya. Kelangkaan bahan bakar minyak seiring berjalannya waktu semakin menjadi-jadi apalagi ditambah dengan harga BBM yang tidak stabil, membuat masyarakat banyak merasa dirugikan karena dampak kelangkaan BBM ini.

$$
\text { Banyaknya tuntutan untuk }
$$

kendaraan yang ramah lingkungan membuat para ahli berpikir untuk menciptakan kendaraan yang ramah lingkungan, namun tetap menghasilkan akselerasi yang baik seperti motor motor pada umumnya. Maka mulai bermunculanlah produk-produk motor listrik, yang mana motor tersebut menggunakan listrik sebagai sumber tenaga yang mampu menghasilkan torsi pada motor, salah satu motor listrik yang berhasil dikembangkan adalah Ganesha
Electric Generasi II karya mahasiswa program studi pendidikan teknik mesin UNDIKSHA, dimana system pengisian baterainya masih memanfaatkan energi listrik PLN sebagai sumber energinya.

Sesuai dengan permasalahan diatas, maka perlu dilakukan suatu pengembangan desain free energy generator berbasis solidworks, dimana luaran desain ini diharapkan mampu diterapkan dalam bentuk prototype yang mampu menghasilkan Arus dan Tegangan yang konsisten, dan ramah lingkungan sebagai sumber energi kelistrikan sekaligus pengisian baterai (recharging) untuk prototype ganesha electric generasi II UNDIKSHA.

\section{METODE PENELITIAN}

Desain penelitian yang digunakan dalam penelitian ini adalah penelitian dan pengembangan. Metode Penelitian dan Pengembangan (Researchand Development) adalah metode penelitian yang digunakan untuk menghasilkan produk tertentu, dan menguji keefektifan produk tersebut. Menurut Sujadi (2003:164) Penelitian dan Pengembangan atau Research and Development (R\&D) adalah suatu proses atau langkah-langkah untuk mengembangkan suatu produk baru, atau menyempurnakan produk yang telah ada, yang dapat dipertanggungjawabkan. Sugiyono. (2015. 407) adapun langkah pelaksanaan strategi penelitian dan pengembangan yang dilakukan untuk menghasilkan produk tertentu untuk menguji keefektifan produk yang dimaksud. Penelitian pengembangan yang dilakukan hanya sampai tahap revisi desain.

Quality Function Deployment (QFD) merupakan suatu metode yang dipakai dalam tahap awal perancangan dan pengembangan produk dimana membuat rancangan kualitas dari suatu produk berdasarkan atas permintaan kualitas dari pemesanan (Customer) atau pasar (Market). QFD merupakan metode yang digunakan untuk mengantisipasi dan menentukan prioritas kebutuhan dan keinginan konsumen, serta menggabungkan kebutuhan dan keinginan 
konsumen tersebut dalam produk barang maupun jasa yang dihasilkan perusahaan.

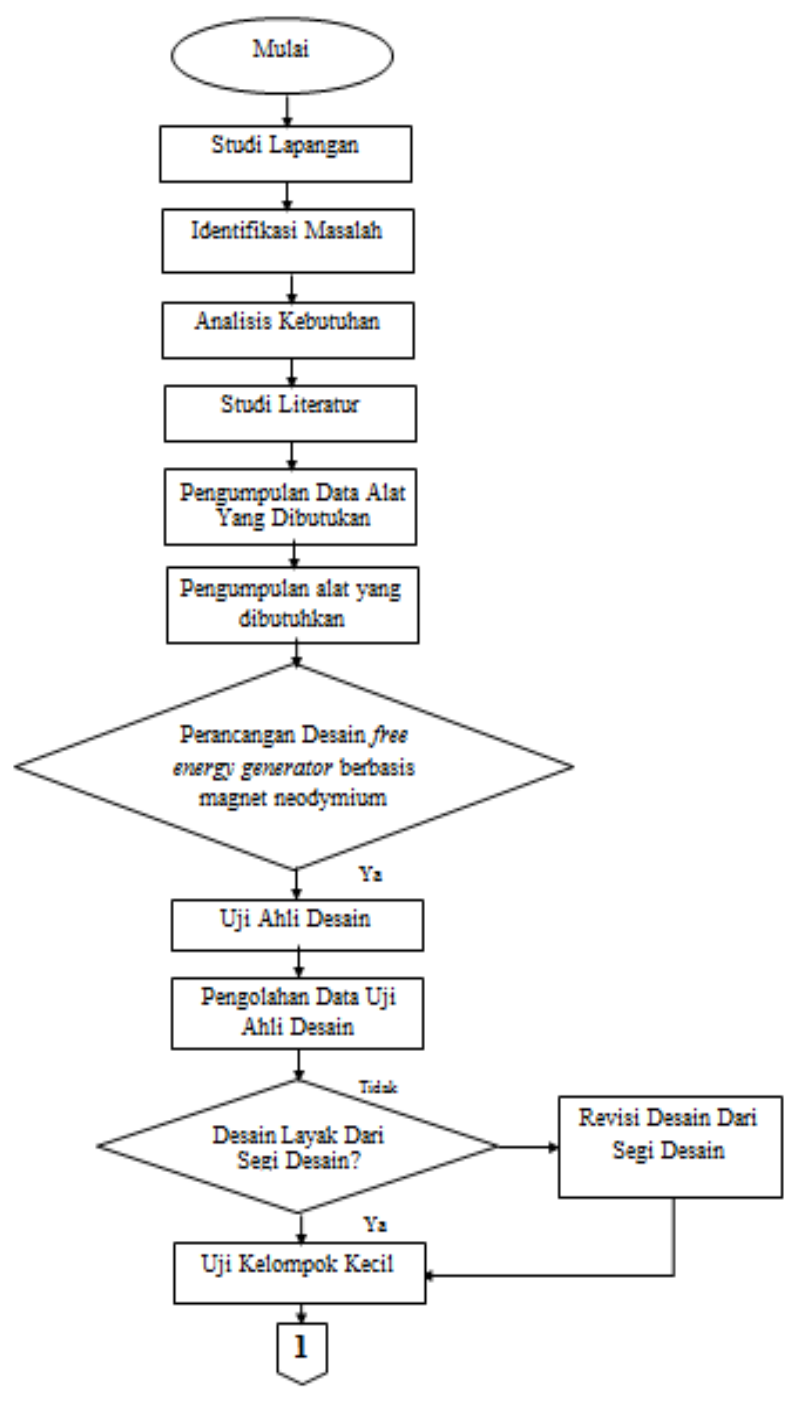

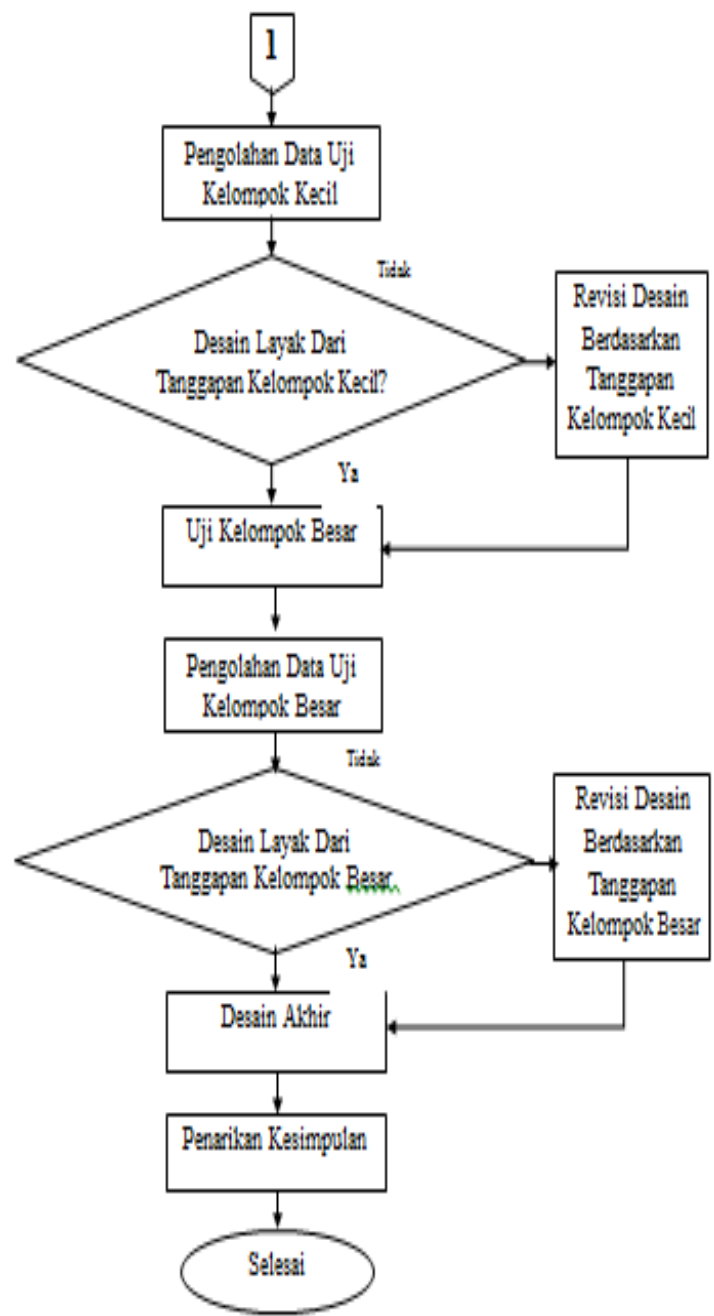

Gambar

Flowchart Penelitian

(Sumber: Komank Bayu Triana. Skripsi. 2019)

Penelitian ini dilakukan berdasarkan konteks permasalahan dalam hal ini menyangkut tentang perangcangan desain free energy generator berbasis magnet neodymium yang akan diterapkan pada prototype ganesha electric generasi II UNDIKSHA. Penelitian pengembangan desain ini menggunakan perangkat lunak Solidworks 2018, dimana memiliki manfaat sebagai rancangan awal sebuah produk yang dikembangkan. Pengujian dilakukan berdasarkan penyebaran angket free energy generator pada Permintaan Kualitas Customer (PKC), uji ahli materi, selanjutnya dilakukan uji kelompok kecil dan uji kelompok besar (uji lapangan).

Untuk mengetahui tingkat kelayakan dari segi desain dan dimensi melalui angket skala ordinal dengan tingkatan 5 (kategori Sangat Setuju/SS), 4 
(kategori Setuju/S), 3 (kategori ragu-ragu), 2 (kategori Tidak Setuju/TS), 1 (kategori Sangat Tidak Setuju/STS) untuk pernyataan positif dan 1 (kategori Sangat Setuju/SS), 2 (kategori Setuju/S), 3 (kategori ragu-ragu), (kategori Tidak Setuju/TS), 5 (kategori Sangat Tidak Setuju/STS) untuk pernyataan bersifat negatif.

\section{HASIL DAN PEMBAHASAN}

Penelitian ini dilakukan berdasarkan konteks permasalahan dalam hal ini menyangkut tentang perangcangan desain free energy generator berbasis magnet neodymium yang akan diterapkan pada prototype ganesha electric generasi II UNDIKSHA. Penelitian pengembangan desain ini menggunakan perangkat lunak Solidworks 2018, dimana memiliki manfaat sebagai rancangan awal sebuah prodak yang dikembangkan.

Dari pengujian yang dilakukan berdasarkan penyebaran angket free energy generator pada Permintaan Kualitas Customer (PKC), uji ahli materi, selanjutnya dilakukan uji kelompok kecil dan uji kelompok besar (uji lapangan),Berdasarkan dari susunan House of Quality (HOQ) yang dikembangkan pada desain free energy generator berbasis neodymium magnets dengan sistem recharging untuk rancangan ganesha electric generasi II Undiksha adalah sebagai berikut :

Tabel

Susunan House of Quality (HOQ)

\begin{tabular}{|l|l|l|}
\hline No. & \multicolumn{1}{|c|}{ PKK } & \multicolumn{1}{|c|}{$\begin{array}{c}\text { Hasil Bobot } \\
\text { PKK (\%) }\end{array}$} \\
\hline 1. & $\begin{array}{l}\text { PKK 4 : Tegangan } \\
\text { 12.5V-14.5V }\end{array}$ & $26,74 \%$ \\
\hline 2. & $\begin{array}{l}\text { PKK 1 : Desain } \\
\text { simple }\end{array}$ & $23,81 \%$ \\
\hline 3. & PKK 5 : Arus 35A. & $22,56 \%$ \\
\hline 4. & $\begin{array}{l}\text { PKK 2 : Dimensi } \\
\text { 240mm x 350mm x }\end{array}$ & $15,18 \%$ \\
\hline 5. & PKK 3 : Harga sesuai & $11,69 \%$ \\
\hline
\end{tabular}

Gambar sket hasil House Of Quality (HOQ) pengembangan desain "Free Energy Generator Berbasis Neodymium Magnets" sebagai berikut.

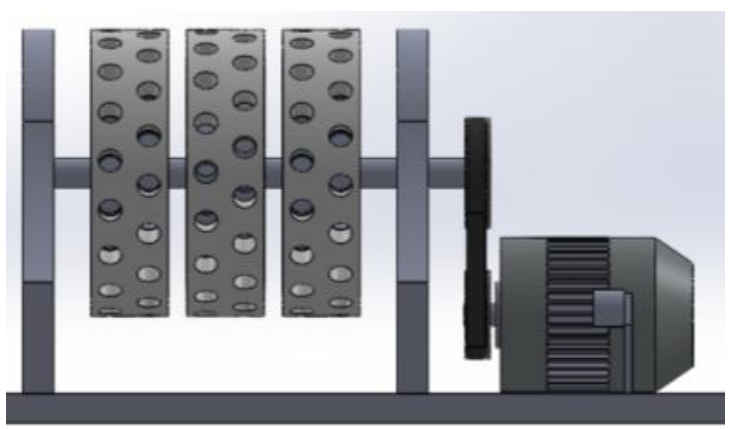

Gambar Sket Hasil HOQ Pengembangan Desain "Free Energy Generator"

(Sumber: Solidworks 2018, Komank Bayu

Triana, Skripsi, 2019)

Untuk mengetahui tingkat kelayakan desain, maka desain yang dibuat perlu diuji oleh ahli materi. Berdasarkan angket hasil ahli materi setelah dihitung maka persentase hasil angket yang didapatkan dari desain free energy generator yaitu 91\% (sangat layak). Untuk data lebih lengkapnya bisa dilihat pada tabel dibawah ini.

Tabel.

Perhitungan Nilai Dari Ahli Materi (Sumber: Angket Ahli Materi)

\begin{tabular}{|c|c|c|c|c|c|c|c|c|c|}
\hline \multicolumn{1}{|c|}{$\begin{array}{c}\text { Nama } \\
\text { Ahli }\end{array}$} & $\mathbf{1}$ & $\mathbf{2}$ & $\mathbf{3}$ & $\mathbf{4}$ & $\mathbf{5}$ & $\mathbf{6}$ & $\mathbf{7}$ & $\mathbf{8}$ & $\mathbf{9}$ \\
\hline $\begin{array}{l}\text { Ketut } \\
\text { Gunawan } \\
\text { S.T., } \\
\text { M.T }\end{array}$ & 4 & $\mathbf{4}$ & $\mathbf{5}$ & $\mathbf{4}$ & $\mathbf{4}$ & $\mathbf{5}$ & $\mathbf{5}$ & 5 & 5 \\
\hline $\begin{array}{c}\text { Rata- } \\
\text { Rata } \\
\text { nilai }\end{array}$ & $\mathbf{4}$ & $\mathbf{4}$ & $\mathbf{5}$ & $\mathbf{4}$ & $\mathbf{4}$ & $\mathbf{5}$ & $\mathbf{5}$ & $\mathbf{5}$ & $\mathbf{5}$ \\
\hline $\begin{array}{l}\text { Total } \\
\text { Nilai }\end{array}$ & \multicolumn{10}{|c|}{} & & & & & & & & \\
\hline
\end{tabular}

Selanjutnya, desain yang telah diuji oleh ahli materi, kemudian diuji pada mahasiswa pendidikan teknik mesin untuk mengetahui tanggapan melalui uji kelompok kecil, dengan hasil presentase tingkat kelayakan sebesar 93,33\% (sangat 
layak) Untuk data lebih lengkapnya bisa dilihat pada tabel dibawah ini.

\section{Tabel}

Perhitungan Nilai Dari Uji Kelompok Kecil (Sumber: Angket Uji Kelompok Kecil)

\begin{tabular}{|c|c|c|c|c|c|c|}
\hline \multirow{2}{*}{$\begin{array}{l}\text { Kode } \\
\text { Siswa }\end{array}$} & \multicolumn{3}{|r|}{ Soal } & \multirow{2}{*}{ Jumlah } & \multirow{2}{*}{ Rata-Rata } & \multirow{2}{*}{ Persentase } \\
\hline & \begin{tabular}{l|l}
1 & 2 \\
\end{tabular} & & \begin{tabular}{l|l|l|l|l|l|}
4 & 5 & 6 & 7 & 8 & 9
\end{tabular} & & & \\
\hline 1 & \begin{tabular}{l|l}
4 & 4
\end{tabular} & 5 & \begin{tabular}{ll|l|l|l|l}
5 & 4 & 5 & 5 & 5 & 5
\end{tabular} & 42 & 4.67 & 93.33 \\
\hline 2 & \begin{tabular}{|l|l}
5 & 4
\end{tabular} & 5 & 4 \begin{tabular}{l|l|l|l|l}
4 & 4 & 5 & 5 & 5
\end{tabular} & 41 & 4.56 & 91.11 \\
\hline 3 & \begin{tabular}{|l|l}
5 & 4
\end{tabular} & 5 & \begin{tabular}{l|l|l|l|l|l|}
5 & 4 & 5 & 4 & 5 & 5 \\
\end{tabular} & 42 & 4.67 & 93.33 \\
\hline 4 & 54 & 5 & \begin{tabular}{ll|l|l|l|l|}
5 & 4 & 5 & 5 & 5 & 5
\end{tabular} & 43 & 4.78 & 95.56 \\
\hline 5 & \begin{tabular}{|l|l}
5 & 4
\end{tabular} & 5 & 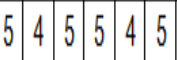 & 42 & 4.67 & 93.33 \\
\hline \multicolumn{4}{|c|}{ Jumlah Total } & 210 & 23.33 & 466.67 \\
\hline \multicolumn{4}{|c|}{ Rata-rata Total } & & 4.67 & \\
\hline \multicolumn{4}{|c|}{ Persentase Total } & & & 93.33 \\
\hline
\end{tabular}

sedangkan untuk hasil tanggapan kelompok besar dengan presentase kelayakan sebesar 91,64\% (sangat layak). Sedangkan data uji kelompok besarnya dapat dilihat pada tabel dibawah ini.

\section{Tabel}

Perhitungan Nilai Dari Uji Kelompok Besar (Sumber: Angket Uji Kelompok Besar)

\begin{tabular}{|c|c|c|c|c|c|c|c|c|c|c|c|c|}
\hline \multirow{2}{*}{$\begin{array}{c}\text { Kode } \\
\text { Siswa }\end{array}$} & \multicolumn{7}{|c|}{ Soal Jumlah } & Rata-Rata & Persentase \\
\hline & $\mathbf{1}$ & 2 & 3 & 4 & 5 & 6 & 7 & $\mathbf{8}$ & 9 & & & \\
\hline 1 & 4 & 4 & 5 & 5 & 4 & 4 & 4 & 4 & 4 & 38 & 4.22 & 84 \\
\hline 2 & 5 & 4 & 5 & 5 & 5 & 4 & 5 & 5 & 5 & 43 & 4.78 & 96 \\
\hline 3 & 5 & 5 & 5 & 5 & 5 & 4 & 5 & 5 & 5 & 44 & 4.89 & 98 \\
\hline 4 & 5 & 4 & 5 & 4 & 4 & 4 & 5 & 5 & 5 & 41 & 4.56 & 91 \\
\hline 5 & 4 & 4 & 5 & 5 & 4 & 4 & 4 & 4 & 5 & 39 & 4.33 & 87 \\
\hline 6 & 4 & 4 & 5 & 5 & 5 & 5 & 4 & 5 & 5 & 42 & 4.67 & 93 \\
\hline 7 & 5 & 4 & 5 & 5 & 4 & 5 & 5 & 5 & 4 & 42 & 4.67 & 93 \\
\hline 8 & 5 & 4 & 5 & 5 & 5 & 4 & 4 & 4 & 5 & 41 & 4.56 & 91 \\
\hline 9 & 4 & 3 & 5 & 4 & 4 & 4 & 4 & 4 & 4 & 36 & 4.00 & 80 \\
\hline 10 & 4 & 4 & 5 & 5 & 4 & 5 & 5 & 5 & 5 & 42 & 4.67 & 93 \\
\hline 11 & 5 & 4 & 5 & 5 & 4 & 4 & 5 & 5 & 5 & 42 & 4.67 & 93 \\
\hline 12 & 5 & 4 & 4 & 4 & 4 & 4 & 4 & 5 & 4 & 38 & 4.22 & 84 \\
\hline 13 & 5 & 4 & 5 & 4 & 4 & 4 & 5 & 4 & 4 & 39 & 4.33 & 87 \\
\hline 14 & 5 & 5 & 5 & 5 & 4 & 4 & 5 & 5 & 5 & 43 & 4.78 & 96 \\
\hline 15 & 5 & 4 & 5 & 4 & 3 & 4 & 4 & 5 & 4 & 38 & 4.22 & 84 \\
\hline 16 & 5 & 5 & 5 & 5 & 4 & 4 & 5 & 5 & 5 & 43 & 4.78 & 96 \\
\hline 17 & 5 & 5 & 5 & 4 & 4 & 4 & 5 & 5 & 5 & 42 & 4.67 & 93 \\
\hline 18 & 5 & 5 & 5 & 5 & 4 & 5 & 5 & 5 & 5 & 44 & 4.89 & 98 \\
\hline 19 & 5 & 5 & 5 & 5 & 4 & 3 & 5 & 5 & 4 & 41 & 4.56 & 91 \\
\hline 20 & 5 & 5 & 5 & 5 & 5 & 4 & 4 & 5 & 5 & 43 & 4.78 & 96 \\
\hline 21 & 4 & 5 & 5 & 4 & 4 & 4 & 5 & 5 & 4 & 40 & 4.44 & 89 \\
\hline 22 & 5 & 5 & 5 & 5 & 5 & 4 & 5 & 5 & 5 & 44 & 4.89 & 98 \\
\hline 23 & 5 & 5 & 5 & 4 & 3 & 4 & 5 & 5 & 4 & 40 & 4.44 & 89 \\
\hline 24 & 5 & 5 & 5 & 5 & 5 & 4 & 5 & 5 & 4 & 43 & 4.78 & 96 \\
\hline 25 & 5 & 4 & 5 & 5 & 4 & 5 & 5 & 5 & 5 & 43 & 4.78 & 96 \\
\hline & Jumlah Total & & & 1031 & $\mathbf{1 1 4 . 5 6}$ & $\mathbf{2 2 9 1}$ \\
\hline & Rata-rata Total & & & & & 4.58 & \\
\hline & Persentase Total & & & & & 91.64 \\
\hline & & & & & & & & & & \\
\hline
\end{tabular}

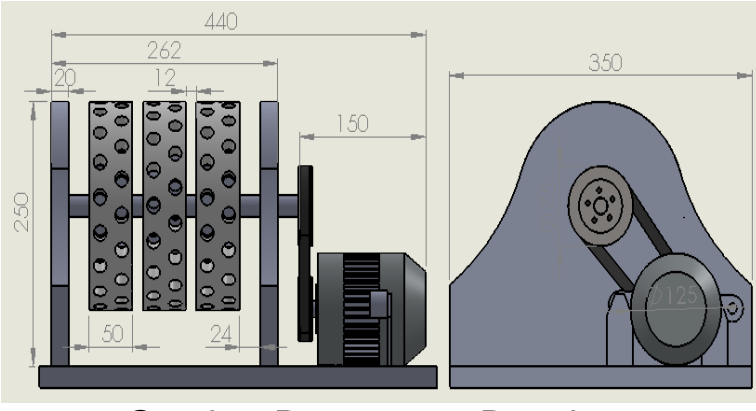

Gambar Rancangan Desain

"Free Energy Generator"

(Sumber: Solidworks 2018, Komank Bayu

Triana, Skripsi, 2019)

Berdasarkan hasil penelitian diatas, maka dapat disusun tabel spesifikasi produk Free Energy Generator Berbasis Magnet Neodymium seperti tabel dibawah ini.

Tabel

Spesifikasi Free Energy Generator Berbasis Magnet Neodymium

\begin{tabular}{|l|l|}
\hline Nama Alat & $\begin{array}{l}\text { Free Energy } \\
\text { Generator }\end{array}$ \\
\hline Jenis & Free Energy \\
\hline Fungsi Alat & Recharging \\
\hline Bentuk Alat & \\
Keseluruhan & \\
Dimensi : & $440 \mathrm{~mm}$ \\
- Panjang & $350 \mathrm{~mm}$ \\
- Lebar & $250 \mathrm{~mm}$ \\
- Tinggi & \\
\hline Bahan dan Kontruksi \\
- Body & \\
- Alternator & POM Acetal \\
- Magnet & $12 \mathrm{~V}, 35 \mathrm{~A}$. \\
- Neodymium & $\mathrm{N} 5215 \times 3 \mathrm{~mm}$ \\
& $15 \times 28 \times 7 \mathrm{~mm}$ \\
B Bantalan & $15 \times 300 \mathrm{~mm}$ \\
- Peramik & $12 \mathrm{~V}, 30 \mathrm{Ah}$ \\
\hline
\end{tabular}

Ada beberapa komponen utama yang dimiliki pada rancangan free energy generator berbasis magnet neodymium ini, diantaranya :

\section{Body}

Body merupakan komponen utama free energy generator, yang berfungsi sebagai pelindung sekaligus sebagai dudukan dari magnet permanen (neodymium). Body terdiri dari dua bagian utama, yaitu: 
a. Rotor

Bagian Rotor (berputar) terletak pada bagian dalam free energy generator, dimana bagian ini nantinya yang akan menghasilkan putaran akibat tolakan dari medan magnet pada stator. Pada satu part rotor, dipasangkan dua baris magnet neodymium N52 15X3 secara melingkar mengelilingi rotor, dimana setiap baris terdapat 18 magnet neodymium N52.

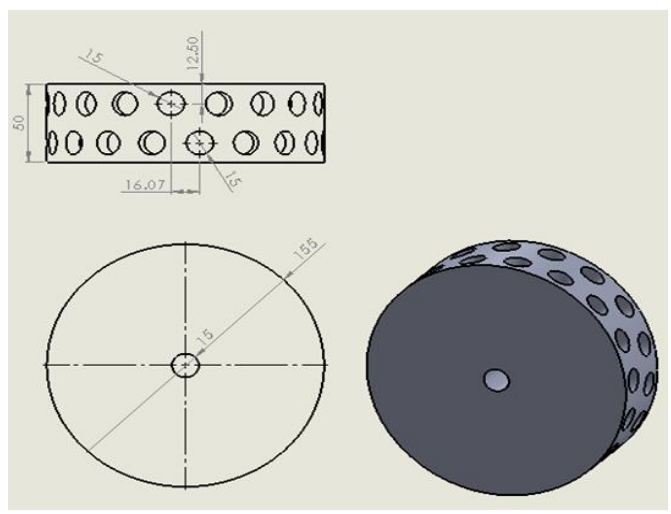

Gambar Rotor

(Sumber: Solidworks 2018, Komank Bayu Triana, Skripsi, 2019)

b. Stator

Bagian Stator (diam) terletak pada bagian luar free energy generator, dimana bagian ini nantinya yang memberikan tolakan pada rotor. Pada satu part stator, dipasangkan dua baris magnet neodymium N52 15X3 secara melingkar mengelilingi stator, dimana setiap baris terdapat 18 magnet neodymium N52.

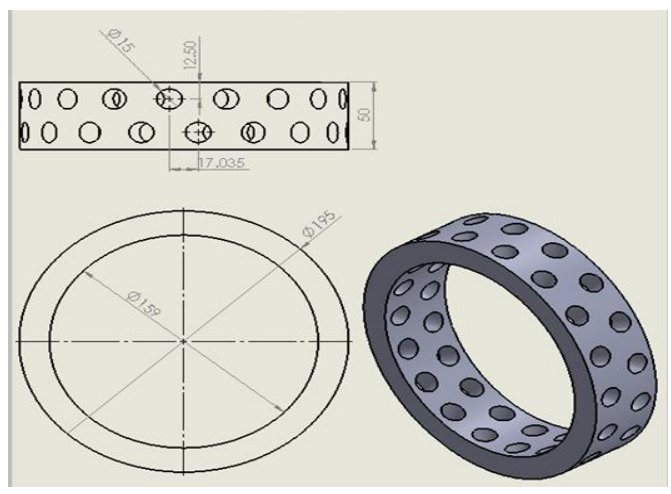

Gambar Stator

(Sumber: Solidworks 2018, Komank Bayu Triana, Skripsi, 2019)

c. Celah Udara (Air Gap)
Celah udara (air gap) merupakan jarak antara stator dan rotor, celah udara yang di pilih adalah $3 \mathrm{~mm}$, dimana terdiri dari celah udara mekanik $1 \mathrm{~mm}$ dan $2 \mathrm{~mm}$ dari resin (stator dan rotor). Semakin kecil penggunaan celah udara, maka akan dapat menghasilkan tegangan induksi atau gaya magnetik yang semakin besar, sehingga mempengaruhi tolakan dan putaran rotor.

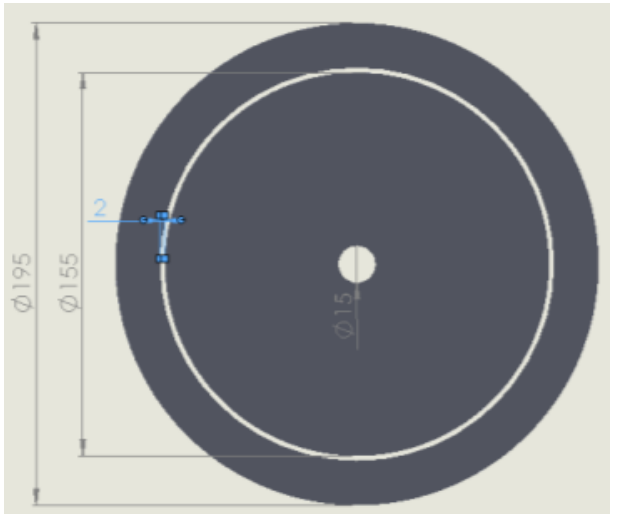

Gambar Celah Udara

(Sumber: Solidworks 2018, Komank Bayu Triana, Skripsi, 2019)

\section{Alternator}

Alternator merupakan suatu alat yang berfungsi untuk mengubah energi mekanik yang didapatkan dari free energy generator menjadi energy listrik berupa arus bolak-balik. Berikut merupakan tabel spesifikasi alternator yang digunakan.

Tabel

Spesifikasi Alternator

\begin{tabular}{|l|l|}
\hline \multicolumn{1}{|c|}{ PARAMETER } & \multicolumn{1}{c|}{ NILAI } \\
\hline Voltage & 12 Volt \\
\hline Current & 35 Ampere \\
\hline Reg.type & $E R$ \\
\hline Fan.type & $E F$ \\
\hline Rotation & CW \\
\hline Pully Class & V1 \\
\hline Mtg.ear Clocking & 12.00 \\
\hline Mtg.ear Hole Size & $M 8 \times 1.25$ \\
\hline
\end{tabular}

3. Magnet Neodymium

Magnet memiliki dua kutub, yaiutu kutub utara dan kutub selatan. Jika dua kutub yang sama didekatkan maka akan menimbulkan gaya tolak-menolak. Sebaliknya jika kutub yang berbeda didekatkan maka akan menimbulkan gaya 
tarik-menarik, aturan ini didasarkan pada prinsip garis gaya magnet. Magnet yang digunakan dalam penelitian ini adalah magnet neodymium (NdFeB) N52 $15 \times 3 \mathrm{~mm}$ dengan spesifikasi sebagai berikut.

Tabel

Spesifikasi Magnet Neodymium

\begin{tabular}{|l|l|}
\hline PARAMETER & NILAI \\
\hline Model number & N52 \\
\hline Certification & $\begin{array}{l}\text { ISO9001:2008; Rohs, Reac } \\
\text { h,SGS }\end{array}$ \\
\hline Type & Permanent \\
\hline Composite & Neodymium Magnet \\
\hline Shape & Cylinder \\
\hline Material & $\begin{array}{l}\text { Sintered Neodymium-Iron- } \\
\text { Boron }\end{array}$ \\
\hline Application & Industrial Magnet \\
\hline
\end{tabular}

4. Bantalan/ Bearing

Bantalan/ Bearing berfungsi sebagai penumpu poros berbeban serta mengurangi gesekan yang terjadi antara poros dengan rumah poros, sehingga putaran yang dihasilkan oleh rotor akan berlangsung secara mulus. Spesifikasi bantalan yang digunakan sebagai berikut.

Tabel

Spesifikasi Bantalan/ Bearing

\begin{tabular}{|l|l|}
\hline \multicolumn{1}{|c|}{ PARAMETER } & \multicolumn{1}{c|}{ NILAI } \\
\hline Nama Merek & ABXG \\
\hline Nomer Model & $15 \times 38 \times 11 \mathrm{~mm}$ \\
\hline $\begin{array}{l}\text { Kekasaran } \\
\text { Permukaan }\end{array}$ & Ra 0.05 \\
\hline Bahan & Besi \\
\hline Torque Capasity & $15 \times 38 \times 11 \mathrm{~mm}$ \\
\hline Pelapisan & Prevent rust oil \\
\hline
\end{tabular}

\footnotetext{
5. Poros/ Shaft

Poros adalah suatu bagian stationer yang berfungsi untuk meneruskan putaran yang dihasilkan rotor, dimana pada umumnya poros berpenampang bulat. Poros utama ini harus terbuat dari bahan yang anti karat serta konsisten dalam suhu dan putaran tinggi, contohnya aluminium, kuningan dan lain-lain.
}

\section{Pulley}

Pulley merupakan salah satu dari berbagai macam transmisi, Pulley memiliki bentuk seperti roda, dimana penggunaanya selalu berpasangan dan dihubungkan dengan sabuk (Belt). Pulley memiliki fungsi sebagai transmisi daya dari penggerak menuju komponen yang digerakkan, mereduksi putaran, mempercepat putaran, dan memperbesar atau memperkecil torsi.

\section{7. $V$-Belt}

Sabuk-V atau $V$-belt adalah salah satu transmisi penghubung yang terbuat dari karet dan mempunyai penampang berbentuk trapesium. $V$-belt juga memiliki keunggulan lain yaitu akan menghasilkan transmisi daya yang besar pada tegangan yang relatif rendah jika dibandingkan dengan transmisi roda gigi dan rantai, sabuk-V bekerja lebih halus dan tak bersuara.

\section{Baterai}

Baterai adalah perangkat yang mengandung sel listrik yang dapat menyimpan energi yang dapat dikonversi menjadi daya. Baterai atau akkumulator adalah sebuah sel listrik dimana didalamnya berlangsung proses elektrokimia yang reversible dengan efisiensinya yang tinggi. Batrai yang akan digunakan dalam penelitian ini adalah batrai dengan kapasitas 12V, 30Ah.

Setelah perancangan dilanjutkan dengan proses pembuatan desain setiap part, kemudian setiap part disatukan (assembely) sehinga menjadi desain free energy generator seutuhnya. Proses pembuatan desain menggunakan aplikasi software Solidworks, berikut ini merupakan dimensi pembuatan desain setiap komponen utama free energy generator berbasis magnet neodymium. 
1. Part Body

a. Rotor

10000000 DOQ00000
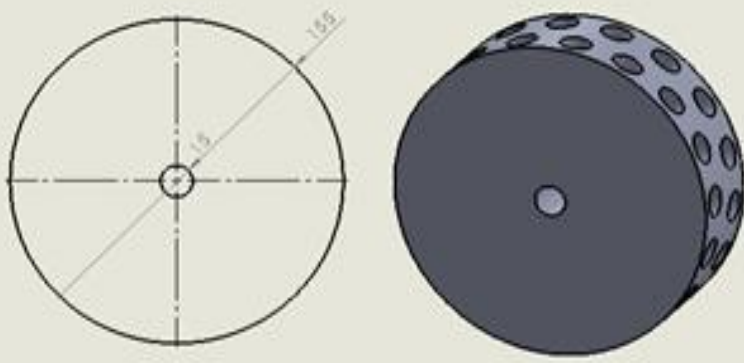

b. Stator

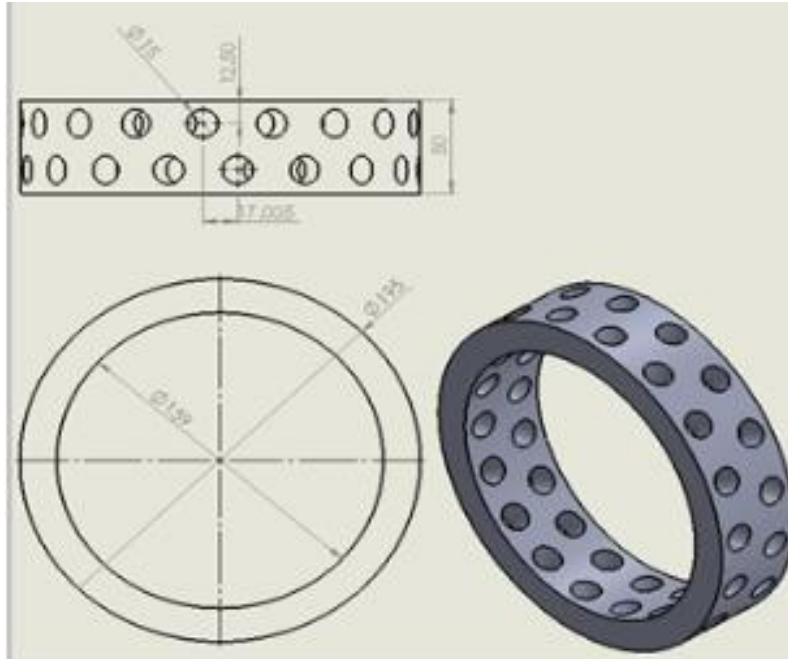

2. Alternator

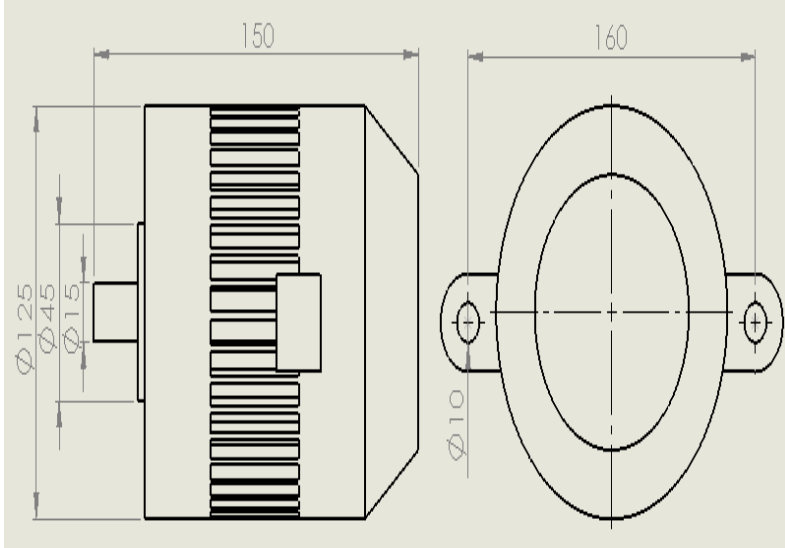

3. Bantalan/ Bearing

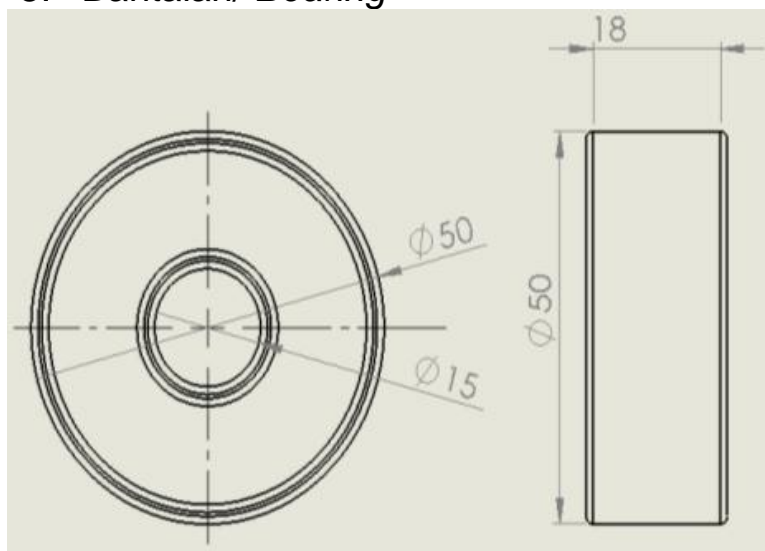

4. Poros/ Shaft

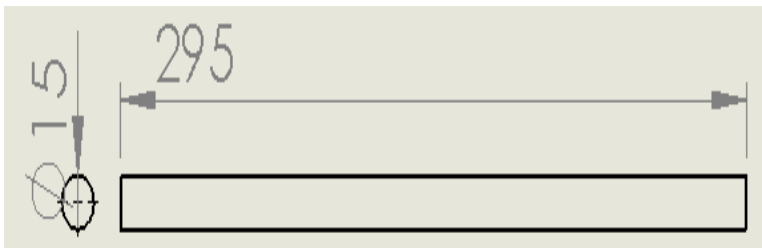

5. Pulley

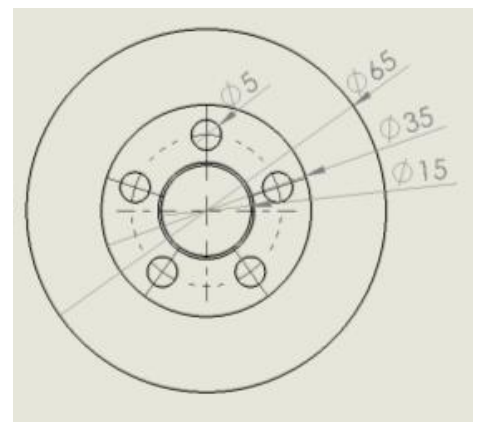

Pully D60mm
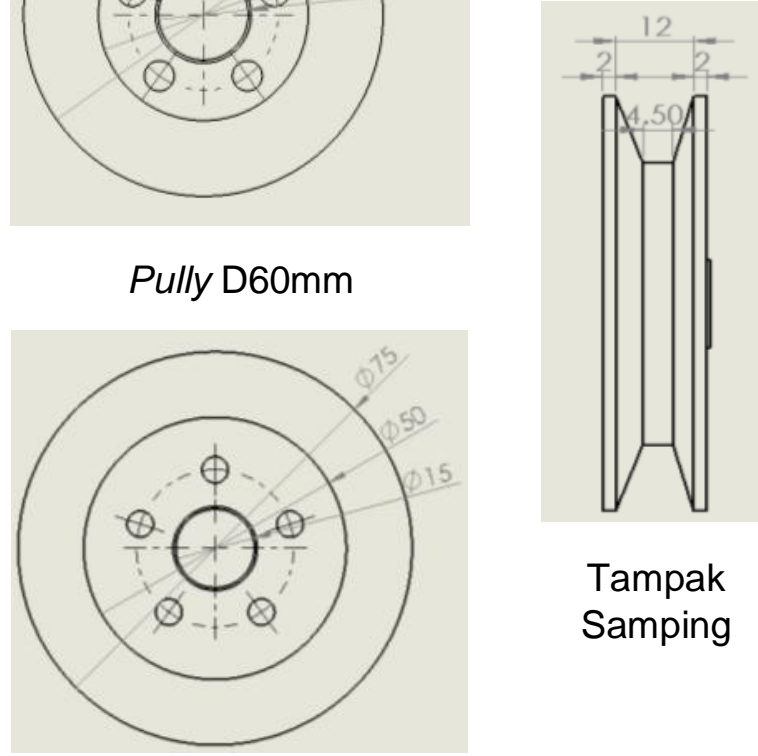

Tampak Samping

Pully D70mm 
6. $V$-Belt

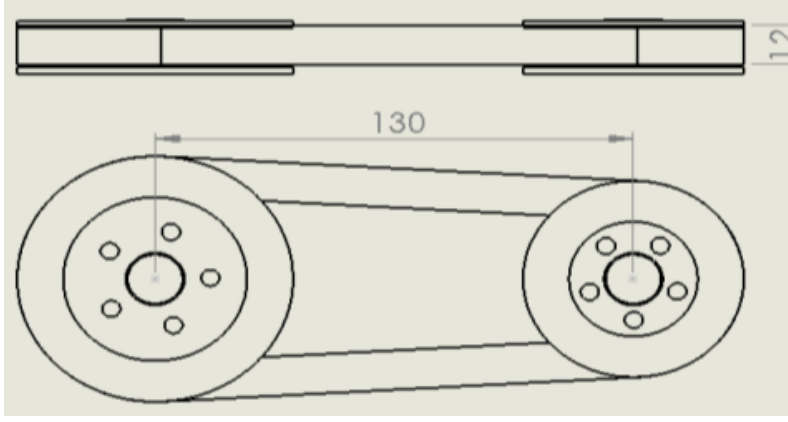

7. Assembely

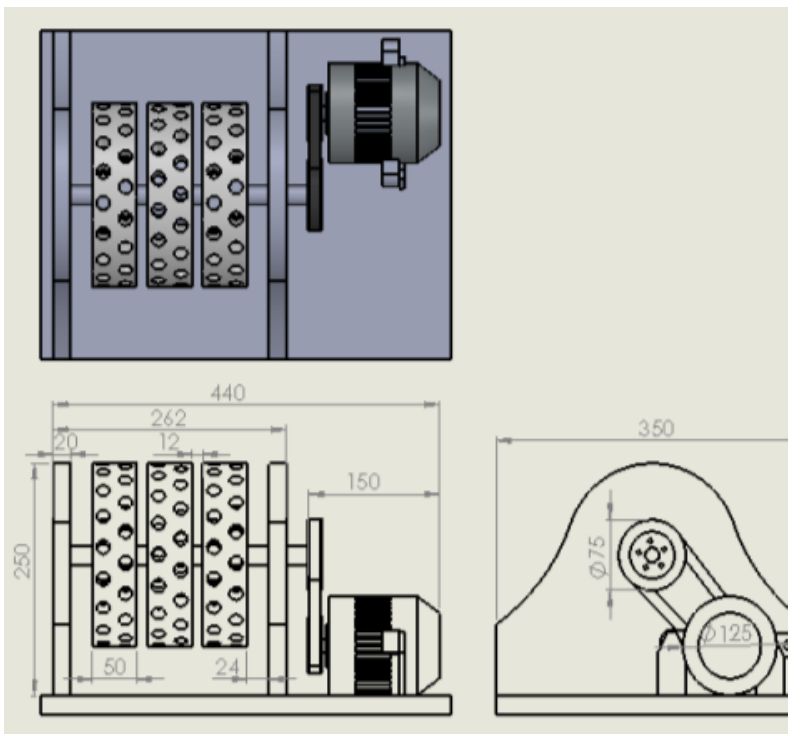

\section{SIMPULAN DAN SARAN}

Adapun simpulan penelitian dan pengembangan desai free energy generator berbahan magnet neodymium ini yaitu.

1. perancangan desain ini menggunakan perangkat lunak Solidworks 2018, Desain yang dirancang adalah free energy generator memiliki fungsi sebagai recharging/ pengisian baterai pada prototype sepeda motor listrik ganesha electric generasi II UNDIKSHA, dimana rancangan desain ini memiliki dimensi panjang $440 \mathrm{~mm}$, lebar $350 \mathrm{~mm}$, dan tinggi $250 \mathrm{~mm}$. Desain rancangan tahap awal ini selanjutnya akan diuji Quality Function Deployment (QFD).

2. Sedangkan untuk mengetahui tingkat kelayakan desain, maka desain yang dibuat perlu diuji oleh ahli materi. Berdasarkan angket hasil ahli desain setelah dihitung maka persentase hasil angket yang didapatkan dari desain free energy generator yaitu 91\% (sangat layak). Selanjutnya, desain yang telah diuji oleh ahli desain, kemudian diuji pada mahasiswa pendidikan teknik mesin untuk mengetahui tanggapan melalui uji kelompok kecil, dengan hasil presentase tingkat kelayakan sebesar 93,33\% (sangat layak) dan hasil tanggapan kelompok besar dengan presentase kelayakan sebesar $91,64 \%$ (sangat layak).

Adapun saran yang dapat diberikan setelah melakukan pengembangan pada desain free energy generator berbasis magnet neodymium yang akan diterapkan pada prototype ganesha electric generasi II UNDIKSHA adalah sebagai berikut.

1. Pemilihan bahan untuk penunjang rancangan free energy generator disesuaikan dengan kebutuhan luaran hasil Tegangan dan Arus yang diinginkan.

2. Untuk desain free energy generator dibuatkan dalam bentuk prototype supaya dapat diterapkan pada rancangan prototype ganesha electric generasi II UNDIKSHA.

\section{DAFTAR RUJUKAN}

Anonim, Diktat Sistem Tenaga Listrik, Program Studi Pendidikan Teknik Mesin, Universitas Pendidikan Ganesha

Gunawan, Hanapi. 1993. Mesin dan Rangkaian Listrik Edisi Keenam. Jakarta: Penerbit Airlangga.

Hartono, Sugito Dan Wihantoro. 2014. "Prototype Generator Magnet Permanen Menggunakan Kumparan Stator Ganda". Berkala Fisika. Volume 17 nomer 4. ISSN : 1410 - 9662. Program Studi Fisika, Fakultas Sains dan Teknik, Universitas Jenderal Soedirman.

Hidayat, Nur.2013. Solidworks 3D Drafting and Design.Bandung:Informatika.

Prasetijo, Hari dan Sugeng Waluyo. 2015. "Optimasi Lebar Celah Udara Generator Axial Magnet Permanen 
Putaran Rendah 1 Fase". Volume 4 Nomer 4. ISSN 2301 - 4156.

Rawendra, yogi subakti. 2017. "Rancang Bangun Pembangkit Listrik Tenaga Magnet' Jurusan Teknik Mesin, konsentrasi Produksi, Politeknik Negeri Padang.

Sugiyono. 2009. Metode Penelitian Kualitatif, Kuantitatif dan R\&D. Bandung: Alfabeta.

Sugiyono. 2013. Metode Penelitian Kualitatif, Kuantitatif dan $R \& D$. Bandung: Alfabeta.

Tegeh. M, dkk. 2014. Model Penelitian Pengembangan. Yogyakarta: Graha Ilmu.

Widoyoko, Eko Putro. 2012. Teknik Penyusun Instrumen Penelitian. Yogyakarta: Pustaka Pelajar.

Wijaya, Ardhians Abdillah, dkk. 2016. "Perancangan Generator Magnet Permanen Dengan Arah Fluks Aksial Untuk Aplikasi Pembangkit Listrik". Volume 4 nomer 2. Jurusan Teknik Elektro, Institut Teknologi Nasional Bandung. 